\title{
Analiza porównawcza wyników finansowych i zadłużenia podsektora samorządowego w Polsce na tle innych państw członkowskich Unii Europejskiej
}

\author{
Ewelina Piekarska*
}

\begin{abstract}
Celem autorki artykutu jest porównanie wyników finansowych i zadtużenia podsektora samorzadowego w Polsce na tle innych państw członkowskich Unii Europejskiej. Określono znaczenie podsektora samorzadowego w systemie finansów publicznych poprzez porównanie dochodów $i$ wydatków przedmiotowego sektora na tle catego sektora finansów publicznych w państwach członkowskich Unii Europejskiej. Ponadto przeprowadzono analize stosowanych regut fiskalnych, które dyscyplinuja wtadze fiskalne w aspekcie ponoszonych wydatków publicznych, finansowania deficytów budżetowych oraz zaciagania zobowiazań finansowych. Omówione zostały także wartości długu publicznego, deficytu (na poziomie zarówno sektora finansów publicznych, jak i podsektora samorzadowego) w państwach członkowskich Unii Europejskiej oraz rozmiary zadtużenia jednostek samorzadu terytorialnego w Polsce na tle ich wyników budżetowych $i$ w relacji do zrealizowanych dochodów budżetowych.
\end{abstract}

Słowa kluczowe: sektor finansów publicznych, podsektor samorządowy, dług, deficyt, wynik finansowy.

Nadesłany: 06.03.17 | Zaakceptowany do druku: 28.04.17

\section{A comparative analysis of financial results and indebtedness of local government subsector in Poland compared to other Member States of the European Union}

The aim of this article is to compare the financial results and indebtedness of local government subsector in Poland compared to other EU Member States. The meaning of local government sector in the public finance system was determined by comparing the income and expenditure of the sector in question against the entire sector of public finance in the EU Member States. In addition, analysis was conducted of the applied fiscal rules that discipline the fiscal authorities in terms of public expenditures incurred, financing of budget deficits and assuming of financial obligations. Also the values of public debt and deficit in the EU Member States were discussed (both at the level of public finances and local government subsector) and the level of indebtedness of local government units in Poland compared to their budget results and in relation to the executed budget incomes.

\footnotetext{
Ewelina Piekarska, mgr - Uniwersytet w Białymstoku, Wydział Ekonomii i Zarządzania, Zakład Ekonomiki i Finansów Samorządu Terytorialnego.

Adres do korespondencji: Uniwersytet w Białymstoku Wydział Ekonomii i Zarządzania, Zakład Ekonomiki i Finansów Samorządu Terytorialnego, ul. Warszawska 63, 15-062 Białystok; e-mail: e.piekarska@uwb.edu.pl.
} 
Keywords: public finance sector, local government subsector, debt, deficit, financial result.

Submitted: 06.03.17 | Accepted: 28.04.17

JEL: H62

\section{Wprowadzenie}

Problematyka zadłużenia podsektora samorządowego ma niekwestionowane znaczenie dla całej gospodarki. Zadłużenie tego podsektora w Polsce w 2015 r. wzrosło o ponad $45 \%$ w porównaniu z rokiem 2009. Jedną z przyczyn tego zjawiska jest fakt, że to właśnie samorząd terytorialny jest głównym inwestorem w sektorze publicznym dzięki realizacji dużej ilości inwestycji. Powoduje to, że znajomość zarówno wyników budżetowych, jak i zadłużenia tego podsektora, jest bardzo ważna. W analizie tej nie można jednak pominąć międzynarodowych powiązań i porównań sytuacji polskiego podsektora samorządowego na tle innych krajów.

Celem niniejszego opracowania jest identyfikacja wyników finansowych oraz zadłużenia podsektora samorzadowego w Polsce na tle innych państw członkowskich Unii Europejskiej. Treści przedstawione w artykule stanowią analizę stanu wiedzy w prezentowanej dziedzinie.

\section{Podsektor samorządowy \\ jako element sektora finansów publicznych}

Jedną z zauważalnych tendencji w państwach Unii Europejskiej jest niewątpliwie rosnąca pozycja podsektora samorządowego $\mathrm{w}$ systemach finansowych poszczególnych krajów. Samorząd terytorialny stał się podmiotem władzy realizującym funkcje państwa na szczeblu lokalnym, a także podmiotem zwiększającym sprawność zarządzania zadaniami publicznymi.

Podział zadań państwa pomiędzy władze centralne i samorządowe jest wynikiem procesu decentralizacji, demokratyzacji, a także ekonomicznej konieczności wykonywania zadań publicznych przez szczebel władzy, który robi to najefektywniej (m.in. w odniesieniu do poniesionych kosztów czy stopnia zaspokojenia potrzeb społeczeństwa) (Jastrzębska, 2012). Efektem takiego działania była reforma samorzadowa dokonana w Polsce w latach 90., która reaktywowała samorząd terytorialny.
Sektor samorządowy jest integralną częścią sektora publicznego (public sector), który koncentruje się na dostarczaniu dóbr i usług publicznych. Sektor ten reprezentuje więc realne zjawiska i procesy gospodarcze (wytwarza określone dobra i usługi). Sektor finansów publicznych (general government sektor) reprezentuje natomiast pieniężne procesy i zjawiska związane $\mathrm{z}$ finansowaniem zadań ze środków publicznych. Jedną z jego charakterystycznych cech jest pozyskiwanie środków w drodze przymusu (podatki, opłaty, cła itp.) (Poniatowicz, Salachna i Perło, 2010).

W krajach członkowskich Unii Europejskiej obowiązuje Europejski System Rachunków Narodowych i Regionalnych ESA 2010, który dzieli sektor general government na cztery podsektory: podsektor centralny (central government), podsektor stanowy (state government), podsektor samorządowy (local government), podsektor związany z systemem finansowania ubepieczeń społecznych (social security funds). W Polsce podsektor centralny jest nazywany sektorem rządowym, natomiast podsektor stanowy występuje jedynie w państwach federalnych.

Znaczenie podsektora samorzadowego w systemie finansów publicznych może być określone poprzez porównanie dochodów i wydatków przedmiotowego podsektora na tle całego sektora finansów publicznych. Obrazują to dane zawarte w tabeli 1, dotyczące sektora finansów publicznych, z uwzględnieniem zarówno podsektora local government, jak i podsektora state government (Niemcy, Austria, Belgia, Hiszpania).

Według danych Eurostatu (Statistics Database) dochody i wydatki w podsektorze state government wykazywane są również w przypadku Hiszpanii, choć hiszpańską monarchię konstytucyjną trudno jednoznacznie zakwalifikować do państw federacyjnych. W odróżnieniu od typowo federacyjnych struktur w innych państwach wspólnoty autonomiczne w Hiszpanii nie mają uprawnień konstytucyjnych, a także suwerenności. To powoduje, że Hiszpania określana jest jako typ państwa pośredniego (regionalnego), znajdującego się na drodze do systemu federacyjnego (Poniatowicz, 2014). 
Rysunek 1. Segmenty sektora general government według ESA 2010

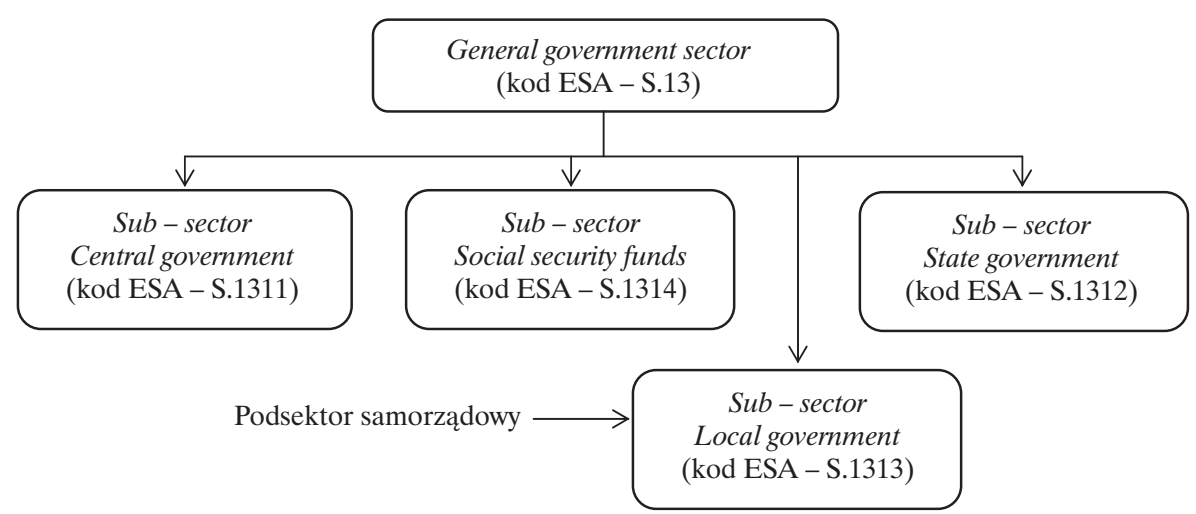

Źródło: opracowanie własne na podstawie rozporządzenia Parlamentu Europejskiego i Rady (UE) nr 549/2013 z dnia 21 maja 2013 r. w sprawie europejskiego systemu rachunków narodowych i regionalnych w Unii Europejskiej.

Tabela 1. Dochody i wydatki sektora finansów publicznych w krajach członkowskich Unii Europejskiej z uwzględnieniem poszczególnych podsektorów (jako \% PKB w 2015 r.; klucz porządkujący kolejność poszczególnych państw - wysokość dochodów podsektora samorządowego jako \% PKB)

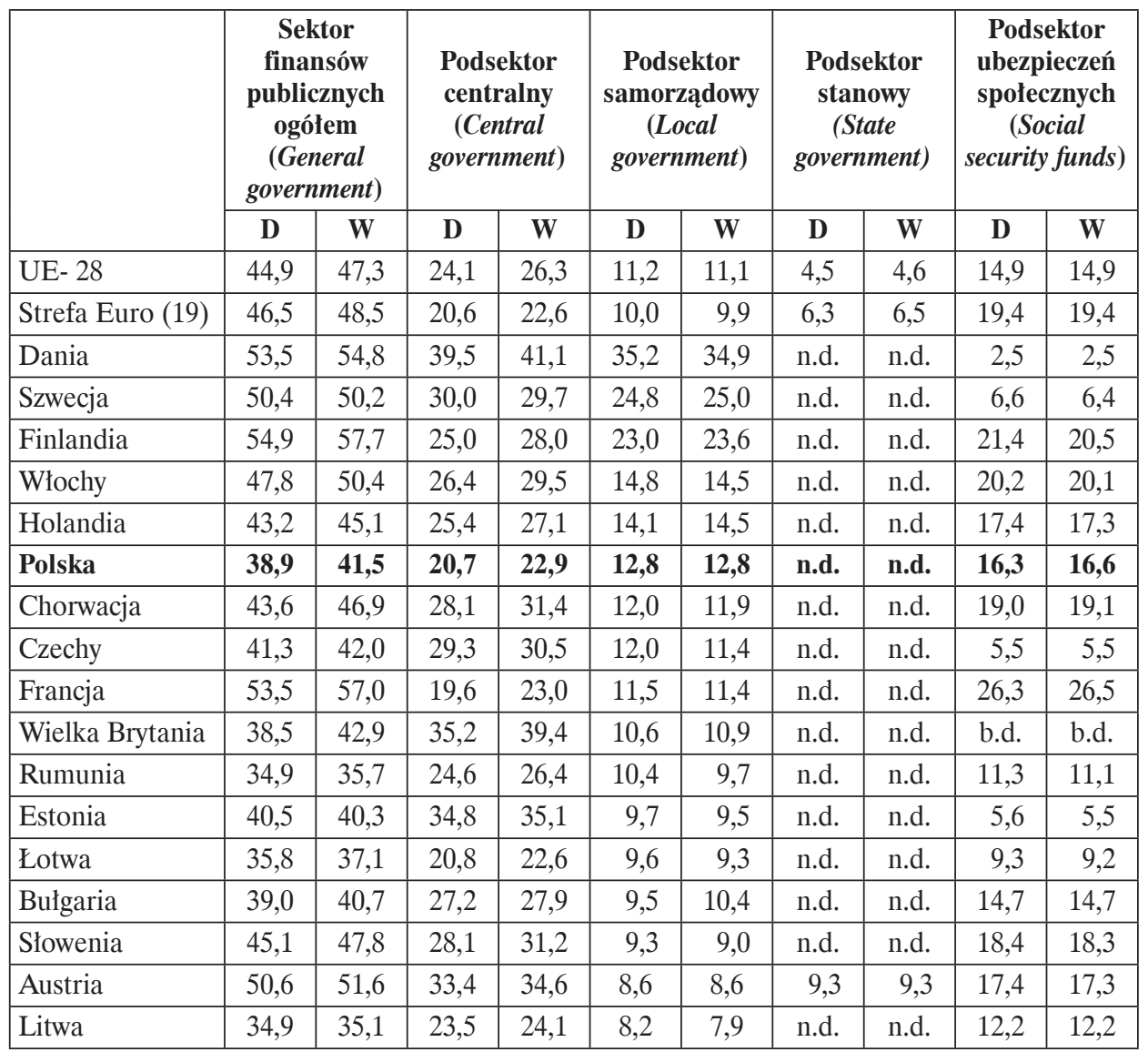

Wydział Zarządzania UW DOI 10.7172/1733-9758.2017.24.10 
Tabela $1 \mathrm{~cd}$.

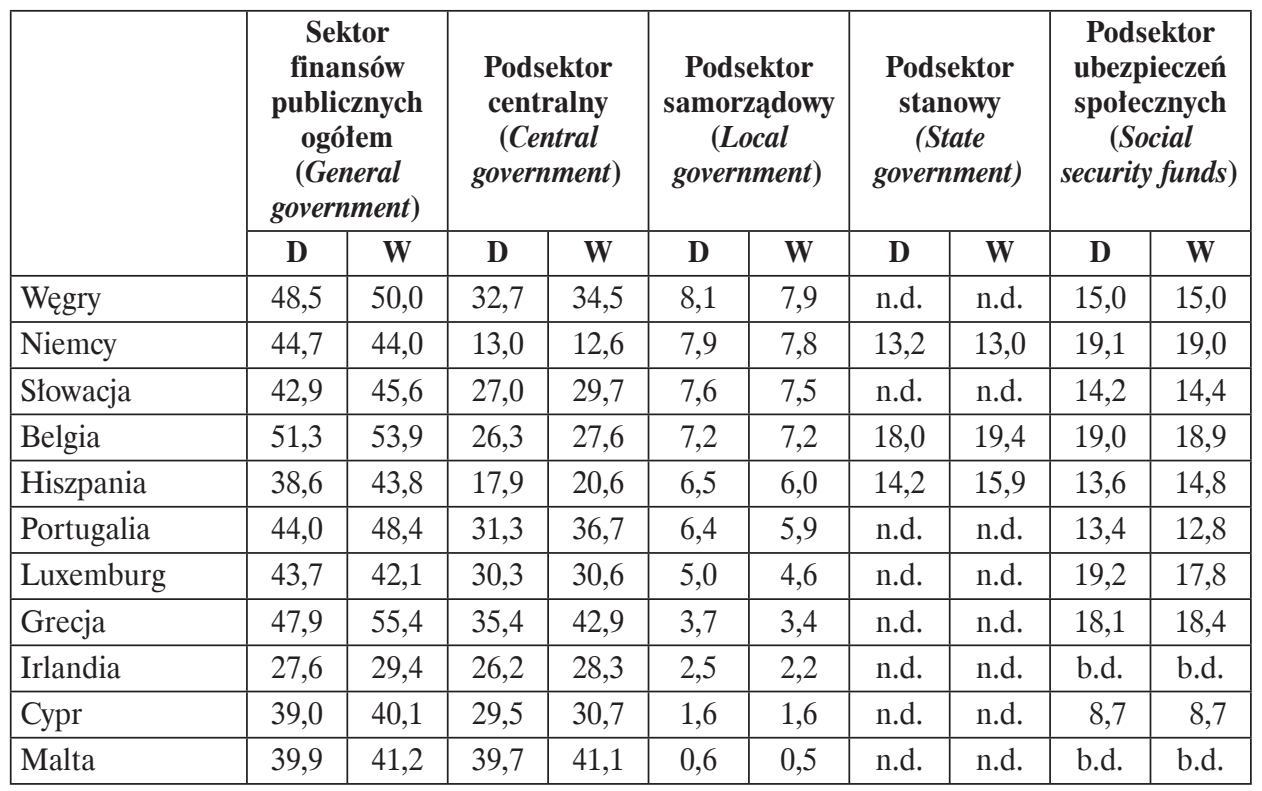

Gdzie: D - dochody; W - wydatki; n.d. - nie dotyczy

Źródło: opracowanie własne na podstawie Statistics Database, Eurostat, protokół dostępu: http:// ec.europa.eu/eurostat/data/database (16.02.2017).

$\mathrm{Z}$ danych zaprezentowanych w tabeli 1 wynika, że pozycja ekonomiczna samorządu terytorialnego $\mathrm{w}$ systemie finansów publicznych jest różna w poszczególnych krajach. W 19 krajach strefy euro pozycja podsektora local government jest zbliżona do pozycji tego podsektora w 28 krajach Unii Europejskiej. Samorząd terytorialny zdecydowanie najmocniejszą pozycję ma w Danii, w której wskaźnik dochodów sektora samorządowego w 2015 r. wyniósł 35,2\% PKB i był zaledwie o $4 \%$ niższy od analogicznego wskaźnika dla sektora centralnego. W przypadku wydatków sektora samorządowego wskaźnik ten osiagnął wartość $34,9 \%$. W obydwu przypadkach przywołane wskaźniki są ponad trzykrotnie wyższe od średniej unijnej. Wysoka pozycja ekonomiczna sektora samorządowego dotyczy również Szwecji i Finlandii (ponad 20-procentowe wskaźniki dochodów i wydatków tego sektora w odniesieniu do PKB). Polska zajęła 6. pozycję w zestawieniu, osiągając wskaźnik udziału dochodów i wydatków podsektora samorządowego na poziomie 12,8\% PKB, czyli wskaźnik zbliżony do średniej unijnej. Z kolei państwem o zdecydowanie najsłabszej pozycji finansowej sektora samo- rządowego jest Malta, w przypadku której wskaźniki dochodów i wydatków sektora kształtowały się odpowiednio na poziomie $0,6 \%$ PKB i $0,5 \%$ PKB.

Warte uwagi są również dochody podsektora samorządowego w wartościach bezwzględnych (tabela 2).

$\mathrm{Z}$ danych zaprezentowanych $\mathrm{w}$ tabeli 2 widać, że łączne dochody podsektora samorządowego w analizowanym okresie (2006-2015) wykazywały tendencje wzrostową (w 2015 roku wzrost o $23 \%$ w porównaniu z rokiem 2006), a w 2015 roku ich wielkość kształtowała się na poziomie $1640,71 \mathrm{mln}$ euro. Najwyższe dochody (ponad 200 mld euro rocznie) dotyczyły Włoch, Francji, Wielkiej Brytanii oraz Niemiec, najniższe zaś Malty oraz Cypru. Polska, mająca dochody na poziomie ok. $50 \mathrm{mld}$ euro rocznie, zalicza się do grupy 10 państw o najwyższym poziomie dochodów podsektora samorządowego (wyższe dochody odnotowano tylko w Danii, Szwecji, Włoszech, Holandii, Francji, Wielkiej Brytanii, Niemczech, Hiszpanii). Warte analizy są także dane dotyczące wielkości wydatków podsektora samorządowego $\mathrm{w}$ państwach członkowskich UE (tabela 3). 


\begin{tabular}{|c|c|c|c|c|c|c|c|c|c|c|}
\hline & 2006 & 2007 & 2008 & 2009 & 2010 & 2011 & 2012 & 2013 & 2014 & 2015 \\
\hline UE-28 (local government) & 1331,50 & 1413,1 & 1443,27 & 1439,32 & 1484,27 & 1502,43 & 1546,16 & 1539,1 & 1575,16 & 1640,71 \\
\hline State government & 504,28 & 541,01 & 554,94 & 554,28 & 545,43 & 564,11 & 610,31 & 608,34 & 5622,21 & 656,8 \\
\hline Dania & 72,43 & 72,96 & 77,16 & 81,44 & 86,74 & 88,41 & 91,52 & 92,54 & 94,28 & 95,56 \\
\hline Szwecja & 78,34 & 83,04 & 83,92 & 77,45 & 90,18 & 97,91 & 105,48 & 110,05 & 107,84 & 110,88 \\
\hline Finlandia & 32,60 & 35,00 & 38,06 & 39,26 & 41,50 & 43,36 & 44,65 & 46,9 & 47,37 & 48,02 \\
\hline Włochy & 219,46 & 234,21 & 242,75 & 253,47 & 245,49 & 241,72 & 243,5 & 240,16 & 240,62 & 243,17 \\
\hline Holandia & 81,27 & 86,58 & 90,12 & 95,73 & 95,33 & 95,68 & 94,51 & 90,18 & 90,33 & 95,59 \\
\hline Polska & 36,48 & 41,59 & 50,64 & 42,44 & 49,45 & 50,18 & 50,36 & 50,93 & 53,83 & 54,89 \\
\hline Chorwacja & 4,76 & 5,15 & 5,58 & 5,14 & 5,35 & 5,11 & 5,22 & 5,29 & 5,31 & 5,28 \\
\hline Czechy & 13,26 & 14,78 & 16,66 & 16,36 & 17,03 & 19,65 & 18,11 & 18,40 & 18,36 & 19,96 \\
\hline Francja & 196,25 & 206,11 & 213,75 & 224,69 & 228,09 & 234,67 & 240,46 & 243,89 & 248,01 & 249,9 \\
\hline Wielka Brytania & 252,42 & 262,16 & 239,32 & 221,04 & 238,60 & 229,67 & 254,92 & 229,14 & 247,81 & 274,73 \\
\hline Rumunia & 8,51 & 11,89 & 12,34 & 10,99 & 11,90 & 12,89 & 12,21 & 13,39 & 14,27 & 16,73 \\
\hline Estonia & 1,23 & 1,46 & 1,68 & 1,52 & 1,48 & 1,57 & 1,70 & 1,79 & 1,83 & 1,97 \\
\hline Lotwa & 1,62 & 2,18 & 2,58 & 2,05 & 2,07 & 2,07 & 2,14 & 2,22 & 2,31 & 2,34 \\
\hline Bułgaria & 1,79 & 2,04 & 2,50 & 2,75 & 2,75 & 2,73 & 2,86 & 3,48 & 3,81 & 4,28 \\
\hline Słowenia & 2,68 & 2,87 & 3,17 & 3,37 & 3,48 & 3,48 & 3,46 & 3,46 & 3,63 & 3,59 \\
\hline Austria (local government) & 20,96 & 22,00 & 23,42 & 23,77 & 24,12 & 25,07 & 26,10 & 27,21 & 28,23 & 29,38 \\
\hline state government & 23,00 & 24,23 & 25,87 & 25,61 & 25,94 & 27,51 & 28,91 & 29,99 & 30,81 & 31,70 \\
\hline
\end{tabular}




\begin{tabular}{|c|c|c|c|c|c|c|c|c|c|c|}
\hline & 2006 & 2007 & 2008 & 2009 & 2010 & 2011 & 2012 & 2013 & 2014 & 2015 \\
\hline Litwa & 1,94 & 2,27 & 2,93 & 2,76 & 3,14 & 3,01 & 3,03 & 2,81 & 2,94 & 3,06 \\
\hline Węgry & 10,90 & 11,71 & 12,27 & 10,86 & 11,51 & 12,12 & 9,65 & 10,13 & 9,63 & 8,85 \\
\hline Niemcy (local government) & 175,36 & 187,89 & 193,64 & 189,67 & 194,77 & 207,19 & 210,63 & 219,18 & 226,30 & 239,77 \\
\hline state government & 287,64 & 309,25 & 316,91 & 309,89 & 317,80 & 339,55 & 348,95 & 367,59 & 382,01 & 398,87 \\
\hline Słowacja & 2,87 & 3,38 & 4,00 & 4,23 & 4,33 & 4,68 & 4,74 & 4,91 & 5,02 & 6,00 \\
\hline Belgia (local government) & 22,38 & 23,56 & 24,97 & 25,61 & 25,98 & 27,17 & 27,58 & 28,58 & 29,07 & 29,73 \\
\hline state government & 46,84 & 49,54 & 52,38 & 52,21 & 53,78 & 58,38 & 60,64 & 62,59 & 63,17 & 73,98 \\
\hline Hiszpania (local government) & 61,85 & 66,28 & 66,7 & 70,39 & 69,56 & 64,60 & 64,85 & 66,42 & 68,31 & 69,79 \\
\hline state government & 146,79 & 157,99 & 159,79 & 166,57 & 147,91 & 138,68 & 171,81 & 148,17 & 146,23 & 152,25 \\
\hline Portugalia & 10,56 & 11,24 & 11,62 & 11,69 & 11,81 & 11,76 & 11,33 & 11,51 & 10,98 & 11,48 \\
\hline Luxemburg & 1,68 & 1,88 & 2,05 & 2,02 & 2,16 & 2,31 & 2,42 & 2,49 & 2,56 & 2,58 \\
\hline Grecja & 7,38 & 7,87 & 8,63 & 9,80 & 8,02 & 6,93 & 6,93 & 7,12 & 6,54 & 6,45 \\
\hline Irlandia & 12,21 & 12,68 & 12,48 & 10,40 & 9,02 & 8,03 & 7,39 & 6,55 & 5,65 & 6,37 \\
\hline Cypr & 0,29 & 0,30 & 0,32 & 0,35 & 0,38 & 0,40 & 0,35 & 0,30 & 0,28 & 0,29 \\
\hline Malta & 0,03 & 0,03 & 0,03 & 0,04 & 0,04 & 0,05 & 0,05 & 0,05 & 0,05 & 0,06 \\
\hline
\end{tabular}

Źródło: opracowanie własne na podstawie Statistics Database, Eurostat, protokół dostępu: http://ec.europa.eu/eurostat/data/database (13.02.2017). 


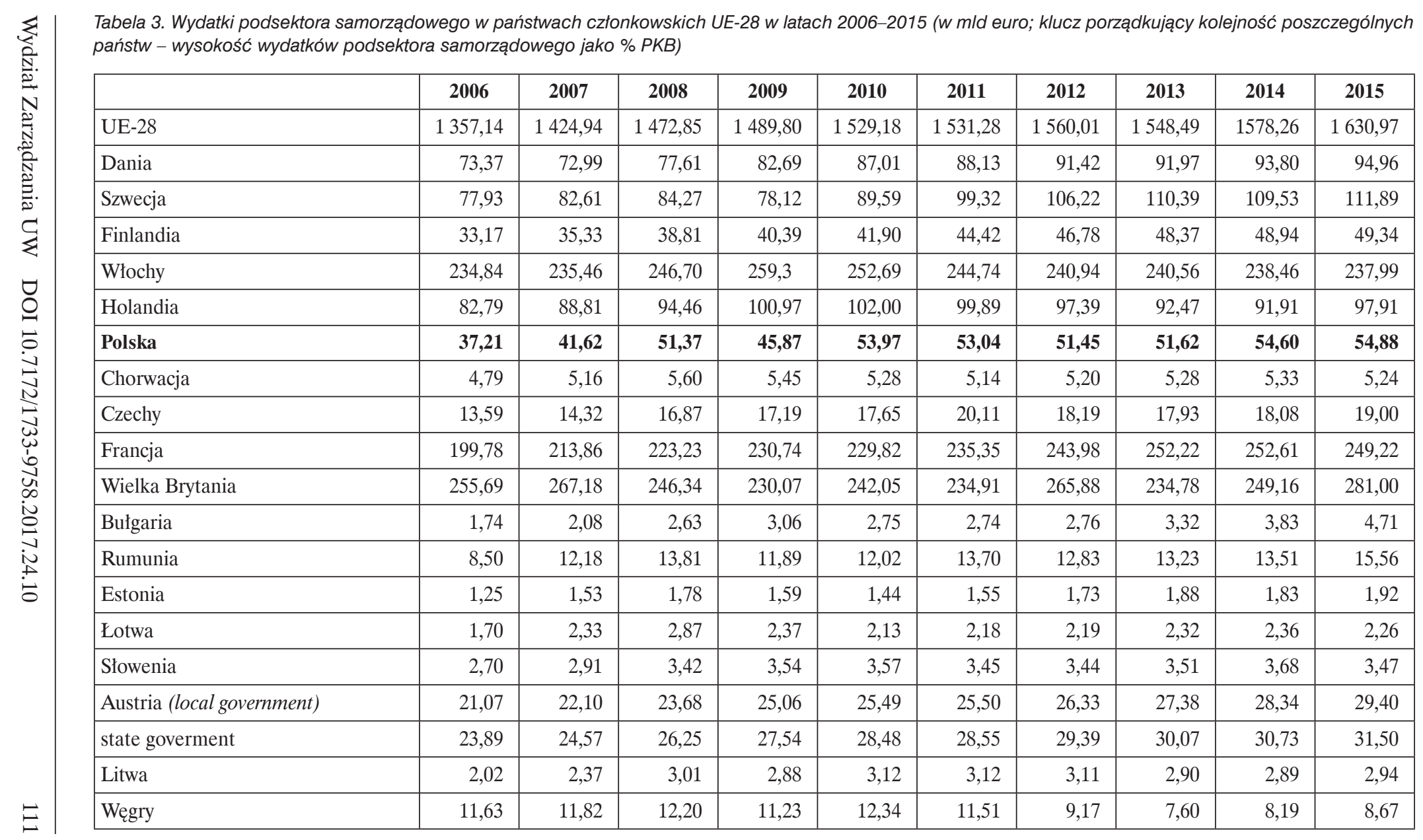




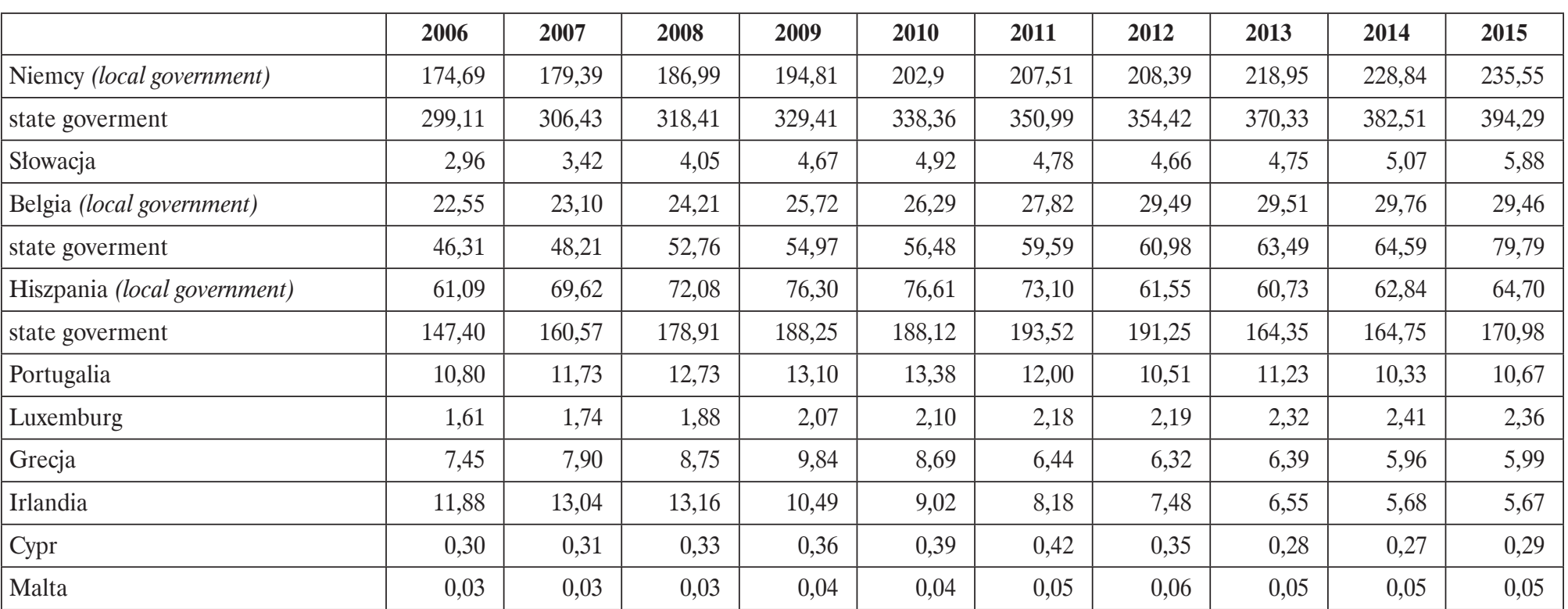

Źródło: opracowanie własne na podstawie Statistics Database, Eurostat, protokół dostępu: http://ec.europa.eu/eurostat/data/database (13.02.2017). 
Analogicznie do wielkości dochodów podesktora samorządowego wydatki wykazywały również tendencję wzrostową. Do grupy 10 państw o najwyższym poziomie wydatków podsektora samorządowego należą te same państwa, co w przypadku wielkości dochodów (Dania, Szwecja, Finlandia, Włochy, Holandia, Polska, Chorwacja, Czechy, Francja, Wielka Brytania). Porównując dane $\mathrm{z}$ tabel 2 i 3, można zauważyć, że w 2015 roku w większej liczbie państw dochody podsektora samorządowego przewyższały wydatki tegoż sektora (w 28 krajach UE w 2015 r. dochody podsektora local government wyniosły 1640,71 mld euro, natomiast wydatki 1630,97 mld euro).

\section{Reguły fiskalne jako sposób stabilizacji finansów publicznych}

Niezwykle istotną kwestią związaną z problematyką zadłużenia jest system mechanizmów i instrumentów reglamentacji poziomu deficytu i długu podsektora samorządowego. Zagadnienie to jest związane $\mathrm{z}$ problematyką tzw. reguł fiskalnych (ang. fiscal rules). Ich zadaniem jest zapewnienie stabilności makroekonomicznej, a także redukcja nadmiernego deficytu budżetowego, dlatego analiza stosowanych reguł fiskalnych będzie poprzedzona wyjaśniem podstawowych pojęć związanych z niniejszym opracowaniem, a mianowicie deficytu i długu publicznego.

Zgodnie z definicją zawartą w ESA 2010 deficyt oznacza pożyczki netto (ang. net borowing) odpowiadające kwocie, którą jednostka czy sektor zmuszone sa pożyczyć od innych jednostek czy sektorów. W polskim ustawodastwie wystepuje kilka terminów zawierających słowo „deficyt”. W kontekście niniejszego opracowania najtrafniejsza jest definicja deficytu sektora finansów publicznych zawarta w art. 7 ustawy z dnia 27 sierpnia 2009 r. o finansach publicznych (Dz.U. 2009 Nr 157 poz. 1240 z późn. zm). Wskazano tam, że deficyt sektora finansów publicznych oznacza ujemną różnicę między dochodami publicznymi a wydatkami publicznymi, ustaloną dla okresu rozliczeniowego po wyeliminowaniu przepływów finansowych między jednostkami tego sektora.

Funkcjonujące w prawie unijnym definicje zarówno deficytu publicznego, jak i długu publicznego zostały sformułowane dla potrzeb stosowania procedury nadmiernego deficytu, oraz - pośrednio - kryteriów konwergencji finansowej państw członkowskich (Bitner, 2016). W ramach Unii Europejskiej obowiązują dwie definicje długu:

- Wprowadzona na podstawie rozporządzenia Rady (WE) Nr 479/2009 z 25 maja 2009 r. o stosowaniu protokołu w sprawie procedury nadmiernego deficytu (ang. Excessive Deficit Procedure - EDP); - funkcjonująca na podstawie Europejskiego Systemu Rachunków Narodowych i Regionalnych we Wspólnocie ESA 2010 (Jóźwiak, 2014).

Dług EPD jest opisywany jako całkowity dług brutto w wartości nominalnej, który występuje na koniec roku i jest skonsolidowany dla sektora publicznego, obejmującego władze centralne, lokalne oraz fundusze ubezpieczeń społecznych. W skład długu EPD wchodzą pozycje gotówki i depozytów, papierów wartościowych innych niż akcje oraz pożyczki. Inny sposób wyceny charakteryzuje dług według ESA 2010, gdzie zobowiązania systemu rachunków narodowych i regionalnych wyceniane są według wartości rynkowej na koniec roku bilansowego. Dług ten posiada także szerszy zakres, gdyż obejmuje dodatkowo pozycje z tytułu akcji i innych udziałów, rezerw techniczno-ubezpieczeniowych oraz pozostałych kwot do zapłacenia (Jóżwiak, 2014). Inaczej, dług według ESA oznacza całkowity dług brutto w wartości nominalnej, istniejący na koniec roku i skonsolidowany pomiędzy i w ramach sektorów władz publicznych.

Terminologia w zakresie długu w polskim ustawodawstwie określa pojęcie państwowego długu publicznego, który stanowi nominalną wartość zobowiązań jednostek zaliczanych do sektora finansów publicznych po wyeliminowaniu wzajemnych zobowiązań między jednostkami tego sektora wynikających z następujących tytułów:

- wyemitowane papiery wartościowe opiewające na wierzytelności pieniężne;

- zaciągnięte kredyty i pożyczki;

- przyjęte depozyty;

- wymagalne zobowiązania: wynikające $z$ odrębnych ustaw oraz prawomocnych orzeczeń sądów lub ostatecznych decyzji administracyjnych i uznanych za bezsporne przez właściwą jednostkę sektora finansów publicznych bedaca dłużnikiem (Lotko i Zawadzka-Pąk, 2016).

Najczęściej występująca definicja długu publicznego wskazuje jednak, że są to 
finansowe zobowiązania władz publicznych (państwowych i samorządowych) z tytułu zaciągniecia pożyczek, które służą pokryciu deficytu budżetowego.

Jak wspomniano we wstępie, jednym $\mathrm{z}$ instrumentów wzmocnienia stabilności finansów publicznych są reguły fiskalne, których podstawową funkcją jest dyscyplinujące oddziaływanie na władze fiskalne w aspekcie ponoszonych wydatków publicznych, finansowania deficytów budżetowych oraz zaciągania zobowiązań finansowych (Poniatowicz, 2014).

Zgodnie z ogólną definicją wprowadzoną przez G. Koptisa i S. Symanskiego reguły fiskalne to permanentne ograniczenie polityki budżetowej, odzwierciedlone we wskaźnikach budżetowych, wskazujących na jej postępy, o charakterze ilociowym lub jakościowym, wprowadzone w sposób stały (Koptis i Symanski, 1998).

W odniesieniu do określania limitów/ ograniczeń reguły fiskalne można podzielić na reguły numeryczne (ilościowe), polegające na ustanowieniu limitów dla wskaźników budżetowych, oraz reguły jakościowe określające w sposób opisowy lub proceduralny wprowadzone ograniczenia rozdysponowywania wydatków publicznych i finansowania deficytów budżetowych (Spychała 2015). Poza powyższym podziałem reguły fiskalne klasyfikowane są według różnych kryteriów, m.in. zasięgu terytorialnego, szczebla sektora publicznego czy rodzaju reguły (Marchewka-Bartkowiak, 2012).

Wyodrębnione $\mathrm{w}$ ramach kryterium zasięgu terytorialnego reguły ponadnaro- dowe mają szczególne znaczenie w kontekście przynależności danego kraju do Unii Gospodarczej i Walutowej. Celem wprowadzenia reguł na szczeblu międzynarodowym - unijnym - jest dyscyplinowanie polityk krajowych. W odniesieniu do niniejszego opracowania warto wskazać reguły na szczeblu międzynarodowym unijnym - do których przestrzegania zobowiązana jest również Polska (Alińska, 2015):

- maksymalny pułap deficytu budżetowego - na poziomie 3\% w skali roku i długu publicznego na poziomie $60 \%$ PKB,

- konieczność utrzymania równowagi budżetowej w średnim okresie, co oznacza, że budżet powinien być zrównoważony lub wykazywać nadwyżkę,

- wzrost wydatków nie powinien przekraczać średniej stopy wzrostu PKB,

- ponadprzeciętne dochody powinny być przeznaczane na redukcję długu,

- za niespełnianie powyższych ograniczeń przewidziano sankcje w postaci ostrzeżenia wydawanego przez Komisję, a w przypadku uporczywego łamania reguły Rada może uchwalić odpowiednie rekomendacje,

- ujednolicenie zasad w dziedzinie zagadnień z zakresu rachunkowości, statystyki oraz procedur prognostycznych (Alińska, 2015).

Wracając do problematyki występujących reguł fiskalnych, warto zwrócić uwage na konstrukcję reguł wyodrębnionych w ujęciu rodzajowym. Konstrukcja czterech głównych grup reguł w tym podziale zaprezentowana jest w tabeli 4 .

Tabela 4. Reguły fiskalne według rodzaju

\begin{tabular}{|l|l|l|l|}
\hline \multicolumn{1}{|c|}{ Rodzaj } & \multicolumn{3}{|c|}{ Konstrukcja } \\
\hline $\begin{array}{l}\text { Reguła salda } \\
\text { budżetowego }\end{array}$ & $\begin{array}{l}\text { Reguła } \\
\text { zrównoważonego } \\
\text { budżetu }\end{array}$ & Złota reguła & $\begin{array}{l}\text { Ograniczenia dotyczące } \\
\text { deficytu budżetowego } \\
\text { (nominalnie lub jako \% PKB) }\end{array}$ \\
\hline $\begin{array}{l}\text { Reguła } \\
\text { zadłużenia }\end{array}$ & $\begin{array}{l}\text { Limit długu } \\
\text { w wartościach } \\
\text { nominalnych }\end{array}$ & $\begin{array}{l}\text { Limit długu w relacji } \\
\text { do PKB lub dochodów } \\
\text { budżetowych }\end{array}$ & $\begin{array}{l}\text { Limit długu w relacji do } \\
\text { zdolności jego obsługi }\end{array}$ \\
\hline $\begin{array}{l}\text { Reguła } \\
\text { wydatkowa }\end{array}$ & $\begin{array}{l}\text { Limit wydatków } \\
\text { w wartościach } \\
\text { nominalnych }\end{array}$ & $\begin{array}{l}\text { Limit wydatków } \\
\text { w wartościach realnych }\end{array}$ & $\begin{array}{l}\text { Nominalna lub realna } \\
\text { stopa wzrostu wydatków } \\
\text { budżetowych }\end{array}$ \\
\hline $\begin{array}{l}\text { Reguła } \\
\text { dochodowa }\end{array}$ & $\begin{array}{l}\text { Poziom obciążeń } \\
\text { podatkowych jako } \\
\% \text { PKB }\end{array}$ & $\begin{array}{l}\text { Reguła oparta na zmianie } \\
\text { stawek podatkowych }\end{array}$ & $\begin{array}{l}\text { Zakres alokacji dodatkowo } \\
\text { wypracowanych dochodów } \\
\text { budżetowych }\end{array}$ \\
\hline
\end{tabular}

Źródło: K. Marchewka-Bartkowiak, Reguły fiskalne w warunkach kryzysu finansów publicznych, „Ekonomia i Prawo” 2012, nr 3, s. 50. 
Reguły salda budżetowego zazwyczaj przybierają postać stałego ograniczenia dopuszczalnego poziomu deficytu $\mathrm{w}$ relacji do PKB, doprowadzając w ten sposób do stanu równowagi budżetowej. W Polsce, od 2011 r., obowiązuje reguła zrównoważonego budżetu bieżącego JST, czyli zasada bilansowania dochodów i wydatków bieżących (tzw. złota reguła), która oznacza wprowadzenie zakazu deficytu operacyjnego (bieżącego) budżetu. Planowane i wykonane wydatki bieżące nie mogą być wyższe niż planowane i wykonane dochody bieżące powiększone o nadwyżkę budżetową z lat ubiegłych i wolne środki. Wykonane wydatki bieżące mogą być wyższe niż planowane i wykonane dochody bieżące powiększone o nadwyżke budżetowa $\mathrm{z}$ lat ubiegłych i wolne środki jedynie o kwotę związaną z realizacją zadań bieżących ze środków pochodzących z UE oraz niepodlegających zwrotowi z pomocy udzielanej przez państwa członkowskie EFTA w przypadku, gdy środki te nie zostały przekazane w danym roku budżetowym (Poniatowicz, 2014). Złota reguła dopuszcza zatem możliwość zwiększenia wydatków budżetowych o charakterze inwestycyjnym.

Określenie wyraźnych ograniczeń, jakie powinna przyjąć relacja długu publicznego do PKB charakteryzuje reguły zadłużenia. Reguły te w Polsce są różnicowane w zależności od poszczególnych szczebli danego sektora (obejmuje zarówno cały sektor finansów publicznych, jak i oddzielnie sektor samorządów terytorialnych). W ramach tej reguły zostały sformułowane limity nałożone poprzez wyznaczenie określonego ilościowego poziomu długu (progi ostrożnościowe wynoszą 50, 55 oraz $60 \%$ PKB). Na szczeblu samorządowym, począwszy od roku 2014, obowiązują nowe limity długu lokalnego - tzw. indywidualne wskaźnik zadłużenia (IWZ) (Marchewka-Bartkowiak, 2012).

IWZ stanowi, że w danym roku budżetowym wartość spłaty zobowiązań wraz z kosztami ich obsługi do dochodów ogółem budżetu jednostki samorządu terytorialnego nie może przekroczyć średniej arytmetycznej $\mathrm{z}$ obliczonych dla ostatnich trzech lat relacji jej dochodów bieżących, powiększonych o dochody ze sprzedaży majątku oraz pomniejszonych o wydatki bieżące do dochodów ogółem budżetu. Wzór arytmetyczny limitu zawarty jest w ustawie o finansach publicznych (Dz.U. 2009 Nr 157 poz. 1240 z późn. zm.).

Zaprezentowane reguły fiskalne $\mathrm{z}$ jednej strony zabezpieczają przed niekontrolowanym powstawaniem deficytu budżetowego i długu, ale z drugiej strony duża ich ilość może powodować pewne ograniczenia w prowadzeniu polityki fiskalnej. Niewątpliwie w Polsce istnieje restrykcyjny system mechanizmów prawnych reglamentacji deficytu i długu publicznego.

\section{Wyniki finansowe i zadłużenie podsektora samorządowego w Polsce na tle krajów Unii Europejskiej}

Analizę wyników finansowych i zadłużenia podsektora samorzadowego warto rozpocząć od przedstawienia wielkości długu publicznego. Wielkości wspomnianego wskaźnika dla poszczególnych państw członkowskich Unii Europejskiej zawarte są w tabeli 5.

W UE-28 relacja długu publicznego do PKB zmniejszyła się z 86,7\% w końcu 2014 r. do $85,0 \%$ w końcu 2015 r. Warto zauważyć, że w 2015 r. łącznie 17 państw członkowskich UE zgłosiło relację długu do PKB przekraczajaca $60 \%$. Na koniec 2015 r. najwyższe poziomy relacji długu do PKB odnotowały: Grecja, Włochy, Portugalia, Cypr i Belgia, zaś najniższe - Estonia, Luksemburg i Bułgaria. W 2015 r. relacja długu do PKB wzrosła w porównaniu z 2014 r. w 10 państwach członkowskich UE, zaś spadła w 18 państwach, w szczególności w Irlandii (-26,6\% PKB), Danii $(-4,4 \%$ PKB $)$ i na Lotwie $(-4,4 \%$ PKB). Największy wzrost relacji długu do PKB pomiędzy 2014 a 2015 r. odnotowano w Finlandii $(3,4 \%)$, Słowenii $(2,2 \%)$ i na Litwie $(2,0 \%)$. Dług publiczny w Polsce w 2015 r. wyniósł 51,1\% PKB, co spowodowało, że Polska znalazła sie na 10. miejscu wśród państw członkowskich o najniższym poziomie długu. Największy wzrost poziomu długu $\mathrm{w}$ analizowanym okresie nastąpił w roku 2010, gdyż w porównaniu z rokiem 2009 dług publiczny zwiększył się o $3,7 \%$.

Jak wskazano w poprzedniej części opracowania, podsektor samorzadowy stanowi istotną część sektora finansów publicznych. Wielkości deficytu tego sektora zostały przedstawione w tabeli 6 . 
Tabela 5. Dług publiczny w Polsce na tle pozostałych państw członkowskich UE-28 w latach 2006-2015 (jako \% PKB)

\begin{tabular}{|c|c|c|c|c|c|c|c|c|c|c|}
\hline & 2006 & 2007 & 2008 & 2009 & 2010 & 2011 & 2012 & 2013 & 2014 & 2015 \\
\hline UE-28 & 60,1 & 57,5 & 60,7 & 72,8 & 78,4 & 81,1 & 83,8 & 85,7 & 86,7 & 85,0 \\
\hline Belgia & 91,0 & 87,0 & 92,5 & 99,5 & 99,7 & 102,3 & 104,1 & 105,4 & 106,5 & 105,8 \\
\hline Bułgaria & 21,0 & 16,3 & 13,0 & 13,7 & 15,3 & 15,2 & 16,7 & 17,0 & 27,0 & 26,0 \\
\hline Czechy & 27,9 & 27,8 & 28,7 & 34,1 & 38,2 & 39,8 & 44,5 & 44,9 & 42,2 & 40,3 \\
\hline Dania & 31,5 & 27,3 & 33,4 & 40,4 & 42,9 & 46,4 & 45,2 & 44,7 & 44,8 & 40,4 \\
\hline Niemcy & 66,5 & 63,7 & 65,1 & 72,6 & 81,0 & 78,7 & 79,9 & 77,5 & 74,9 & 71,2 \\
\hline Estonia & 4,4 & 3,7 & 4,5 & 7,0 & 6,6 & 6,1 & 9,7 & 10,2 & 10,7 & 10,1 \\
\hline Irlandia & 23,6 & 23,9 & 42,4 & 61,7 & 86,3 & 109,6 & 119,5 & 119,5 & 105,2 & 78,6 \\
\hline Grecja & 103,6 & 103,1 & 109,4 & 126,7 & 146,2 & 172,1 & 159,6 & 177,4 & 179,7 & 177,4 \\
\hline Hiszpania & 38,9 & 35,5 & 39,4 & 52,7 & 60,1 & 69,5 & 85,7 & 95,4 & 100,4 & 99,8 \\
\hline Francja & 64,4 & 64,3 & 68,0 & 78,9 & 81,6 & 85,2 & 89,5 & 92,3 & 95,3 & 96,2 \\
\hline Chrowacja & 38,9 & 37,7 & 39,6 & 49,0 & 58,3 & 65,2 & 70,7 & 82,2 & 86,6 & 86,7 \\
\hline Włochy & 102,6 & 99,8 & 102,4 & 112,5 & 115,4 & 116,5 & 123,3 & 129,0 & 131,9 & 132,3 \\
\hline Cypr & 58,7 & 53,5 & 44,7 & 53,4 & 55,8 & 65,2 & 79,3 & 102,2 & 107,1 & 107,5 \\
\hline Łotwa & 9,9 & 8,4 & 18,7 & 36,6 & 47,4 & 42,8 & 41,3 & 39,0 & 40,7 & 36,3 \\
\hline Litwa & 17,2 & 15,9 & 14,6 & 28,0 & 36,2 & 37,2 & 39,8 & 38,7 & 40,5 & 42,7 \\
\hline Luxemburg & 7,9 & 7,8 & 15,1 & 16,0 & 19,9 & 18,8 & 21,8 & 23,5 & 22,7 & 22,1 \\
\hline Węgry & 64,6 & 65,6 & 71,6 & 77,8 & 80,5 & 80,7 & 78,2 & 76,6 & 75,7 & 74,7 \\
\hline Malta & 64,6 & 62,4 & 62,7 & 67,8 & 67,6 & 70,0 & 67,6 & 68,4 & 67,0 & 64,0 \\
\hline Holandia & 44,8 & 42,7 & 54,8 & 56,9 & 59,3 & 61,6 & 66,4 & 67,7 & 67,9 & 65,1 \\
\hline Austria & 67,3 & 65,1 & 68,8 & 80,1 & 82,8 & 82,6 & 82,0 & 81,3 & 84,4 & 85,5 \\
\hline Polska & 46,9 & 44,2 & 46,3 & 49,4 & 53,1 & 54,1 & 53,7 & 55,7 & 50,2 & 51,1 \\
\hline Portugalia & 69,2 & 68,4 & 71,7 & 83,6 & 96,2 & 111,4 & 126,2 & 129,0 & 130,6 & 129,0 \\
\hline Rumunia & 12,3 & 12,7 & 13,2 & 23,2 & 29,9 & 34,2 & 37,3 & 37,8 & 39,4 & 37,9 \\
\hline Słowenia & 26,0 & 22,8 & 21,8 & 34,6 & 38,4 & 46,6 & 53,9 & 71,0 & 80,9 & 83,1 \\
\hline Słowacja & 31,0 & 30,1 & 28,5 & 36,3 & 41,2 & 43,7 & 52,2 & 54,7 & 53,6 & 52,5 \\
\hline Finlandia & 38,2 & 34,0 & 32,7 & 41,7 & 47,1 & 48,5 & 53,9 & 56,5 & 60,2 & 63,6 \\
\hline Szwecja & 43,7 & 39,0 & 37,5 & 41,0 & 38,3 & 37,5 & 37,8 & 40,4 & 45,2 & 43,9 \\
\hline Wielka Brytania & 41,0 & 42,0 & 50,2 & 64,5 & 76,0 & 81,6 & 85,1 & 86,2 & 88,1 & 89,1 \\
\hline
\end{tabular}

Źródło: opracowanie własne na podstawie Statistics Database, Eurostat, protokół dostępu: http://ec.europa.eu/eurostat/data/database (13.02.2017). 
Tabela 6. Deficyt sektora finansów publicznych w Polsce na tle pozostałych państw członkowskich UE-28 w latach 2006-2015 (jako \% PKB)

\begin{tabular}{|c|c|c|c|c|c|c|c|c|c|c|}
\hline & 2006 & 2007 & 2008 & 2009 & 2010 & 2011 & 2012 & 2013 & 2014 & 2015 \\
\hline UE-28 & $-1,6$ & $-0,9$ & $-2,4$ & $-6,6$ & $-6,4$ & $-4,6$ & $-4,3$ & $-3,3$ & $-3,0$ & $-2,4$ \\
\hline Belgia & 0,2 & 0,1 & $-1,1$ & $-5,4$ & $-4,0$ & $-4,1$ & $-4,2$ & $-3,0$ & $-3,1$ & $-2,5$ \\
\hline Bułgaria & 1,8 & 1,1 & 1,6 & $-4,1$ & $-3,1$ & $-2,0$ & $-0,3$ & $-0,4$ & $-5,5$ & $-1,7$ \\
\hline Czechy & $-2,3$ & $-0,7$ & $-2,1$ & $-5,5$ & $-4,4$ & $-2,7$ & $-3,9$ & $-1,2$ & $-1,9$ & $-0,6$ \\
\hline Dania & 5,0 & 5,0 & 3,2 & $-2,8$ & $-2,7$ & $-2,1$ & $-3,5$ & $-1,1$ & 1,5 & $-1,7$ \\
\hline Niemcy & $-1,7$ & 0,2 & $-0,2$ & $-3,2$ & $-4,2$ & $-1,0$ & 0,0 & $-0,2$ & 0,3 & 0,7 \\
\hline Estonia & 2,9 & 2,7 & $-2,7$ & $-2,2$ & 0,2 & 1,2 & $-0,3$ & $-0,2$ & 0,7 & 0,1 \\
\hline Irlandia & 2,8 & 0,3 & $-7,0$ & $-13,8$ & $-32,1$ & $-12,6$ & $-8,0$ & $-5,7$ & $-3,7$ & $-1,9$ \\
\hline Grecja & $-5,9$ & $-6,7$ & $-10,2$ & $-15,1$ & $-11,2$ & $-10,3$ & $-8,8$ & $-13,2$ & $-3,6$ & $-7,5$ \\
\hline Hiszpania & 2,2 & 2,0 & $-4,4$ & $-11,0$ & $-9,4$ & $-9,6$ & $-10,5$ & $-7,0$ & $-6,0$ & $-5,1$ \\
\hline Francja & $-2,3$ & $-2,5$ & $-3,2$ & $-7,2$ & $-6,8$ & $-5,1$ & $-4,8$ & $-4,0$ & $-4,0$ & $-3,5$ \\
\hline Chrowacja & $-3,4$ & $-2,4$ & $-2,8$ & $-6,0$ & $-6,2$ & $-7,8$ & $-5,3$ & $-5,3$ & $-5,4$ & $-3,3$ \\
\hline Włochy & $-3,6$ & $-1,5$ & $-2,7$ & $-5,3$ & $-4,2$ & $-3,7$ & $-2,9$ & $-2,7$ & $-3,0$ & $-2,6$ \\
\hline Cypr & $-1,0$ & 3,2 & 0,9 & $-5,4$ & $-4,7$ & $-5,7$ & $-5,8$ & $-4,9$ & $-8,8$ & $-1,1$ \\
\hline Łotwa & $-0,6$ & $-0,7$ & $-4,1$ & $-9,1$ & $-8,5$ & $-3,4$ & $-0,8$ & $-0,9$ & $-1,6$ & $-1,3$ \\
\hline Litwa & $-0,3$ & $-0,8$ & $-3,1$ & $-9,1$ & $-6,9$ & $-8,9$ & $-3,1$ & $-2,6$ & $-0,7$ & $-0,2$ \\
\hline Luxemburg & 2,0 & 4,2 & 3,4 & $-0,7$ & $-0,7$ & 0,5 & 0,3 & 1,0 & 1,5 & 1,6 \\
\hline Węgry & $-9,3$ & $-5,1$ & $-3,6$ & $-4,6$ & $-4,5$ & $-5,5$ & $-2,3$ & $-2,6$ & $-2,1$ & $-1,6$ \\
\hline Malta & $-2,6$ & $-2,3$ & $-4,2$ & $-3,3$ & $-3,2$ & $-2,5$ & $-3,6$ & $-2,6$ & $-2,1$ & $-1,4$ \\
\hline Holandia & 0,2 & 0,2 & 0,2 & $-5,4$ & $-5,0$ & $-4,3$ & $-3,9$ & $-2,4$ & $-2,3$ & $-1,9$ \\
\hline Austria & $-2,6$ & $-1,4$ & $-1,5$ & $-5,4$ & $-4,5$ & $-2,6$ & $-2,2$ & $-1,4$ & $-2,7$ & $-1,0$ \\
\hline Polska & $-3,6$ & $-1,9$ & $-3,6$ & $-7,3$ & $-7,3$ & $-4,8$ & $-3,7$ & $-4,1$ & $-3,4$ & $-2,6$ \\
\hline Portugalia & $-4,3$ & $-3,0$ & $-3,8$ & $-9,8$ & $-11,2$ & $-7,4$ & $-5,7$ & $-4,8$ & $-7,2$ & $-4,4$ \\
\hline Rumunia & $-2,1$ & $-2,8$ & $-5,5$ & $-9,5$ & $-6,9$ & $-5,4$ & $-3,7$ & $-2,1$ & $-0,8$ & $-0,8$ \\
\hline Słowenia & $-1,2$ & $-0,1$ & $-1,4$ & $-5,9$ & $-5,6$ & $-6,7$ & $-4,1$ & $-15,0$ & $-5,0$ & $-2,7$ \\
\hline Słowacja & $-3,6$ & $-1,9$ & $-2,4$ & $-7,8$ & $-7,5$ & $-4,3$ & $-4,3$ & $-2,7$ & $-2,7$ & $-2,7$ \\
\hline Finlandia & 3,9 & 5,1 & 4,2 & $-2,5$ & $-2,6$ & $-1,0$ & $-2,2$ & $-2,6$ & $-3,2$ & $-2,8$ \\
\hline Szwecja & 2,2 & 3,3 & 1,9 & $-0,7$ & $-0,1$ & $-0,2$ & $-1,0$ & $-1,4$ & $-1,6$ & 0,2 \\
\hline Wielka Brytania & $-2,7$ & $-2,9$ & $-4,9$ & $-10,2$ & $-9,6$ & $-7,6$ & $-8,3$ & $-5,7$ & $-5,7$ & $-4,3$ \\
\hline
\end{tabular}

Źródło: opracowanie własne na podstawie Statistics Database, Eurostat, protokół dostępu: http://ec.europa.eu/eurostat/data/database (16.02.2017). 
Relacja deficytu sektora finansów publicznych do PKB w 28 krajach Unii Europejskiej zmniejszyła się $\mathrm{z}-3,0 \%$ w 2014 r. do $-2,4 \%$ w 2015 r. Zgodnie $\mathrm{z}$ danymi zawartymi $\mathrm{w}$ tabeli 6 , cztery państwa członkowskie - Luksemburg, Niemcy, Szwecja i Estonia - odnotowały w 2015 r. nadwyżki budżetowe, jednak to tylko w przypadku Luksemburgu nadwyżka utrzymywała się od kilku lat (od 2011). 18 państw członkowskich UE, tj. Litwa, Czechy, Rumunia, Cypr, Austria, Łotwa, Malta, Holandia, Węgry, Bułgaria, Dania, Irlandia, Belgia, Włochy, Polska, Finlandia, Słowacja i Słowenia, odnotowało natomiast w 2015 r. poziomy deficytu niższe niż $-3,0 \%$ PKB. W kontekście przestrzegania unijnych reguł fiskalnych, w 2015 r. w sześciu państwach członkowskich wskaźniki deficytu przekroczyły $-3,0 \%$ PKB - w Grecji, Hiszpanii, Wielkiej Brytanii, Portugalii, Francji i Chorwacji. Te sześć państw członkowskich, w których wskaźniki deficytu przekroczyły $-3,0 \%$ PKB, zgłosiło także deficyt przekraczający $-3,0 \%$ w każdym $\mathrm{z}$ trzech poprzednich lat. W przypadku Polski deficyt wyniósł w 2015 r. $-2,6 \%$ i był mniejszy niż w 2014 r. o $0,8 \%$. W analizowanym okresie najwyższy poziom deficytu w Polsce odnotowano w 2009 i 2010 roku - analogicznie do średniej unijnej.

Zadłużenie podsektora local government przedstawiono $\mathrm{w}$ tabeli 7 . W wielu przypadkach występuje brak danych ze względu

Tabela 7 Zadłużenie podsektora local government w Polsce na tle pozostałych państw członkowskich UE-28 w latach 2006-2015 jako \% PKB (według ESA 2010)

\begin{tabular}{|c|c|c|c|c|c|c|c|c|c|c|}
\hline & 2006 & 2007 & 2008 & 2009 & 2010 & 2011 & 2012 & 2013 & 2014 & 2015 \\
\hline UE-28 & $:$ & $:$ & $:$ & $:$ & $:$ & : & 6,0 & 6,1 & 6,1 & 5,9 \\
\hline Belgia (local government) & 5,4 & 5,3 & 5,0 & 4,9 & 5,2 & 5,2 & 5,5 & 5,7 & 5,9 & 5,7 \\
\hline state government & 7,8 & 7,5 & 8,0 & 10,8 & 11,3 & 11,7 & 12,0 & 11,9 & 12,5 & 12,6 \\
\hline Bułgaria & $:$ & : & $:$ & $:$ & $:$ & : & 1,2 & 1,1 & 1,2 & 1,4 \\
\hline Czechy & : & $:$ & $:$ & : & : & : & 2,8 & 2,8 & 2,7 & 2,4 \\
\hline Dania & : & $:$ & $:$ & : & : & $:$ & 7,0 & 7,3 & 7,3 & 7,4 \\
\hline $\begin{array}{l}\text { Niemcy } \\
\text { (local government) }\end{array}$ & : & $:$ & $:$ & : & $:$ & : & 5,4 & 5,3 & 5,2 & 5,0 \\
\hline state government & : & : & $:$ & : & : & $:$ & 24,8 & 23,5 & 22,5 & 21,5 \\
\hline Estonia & : & $:$ & $:$ & : & $:$ & 3,2 & 3,2 & 3,6 & 3,8 & 3,6 \\
\hline Irlandia & : & : & : & : & $:$ & : & 2,9 & 2,7 & 2,6 & 1,6 \\
\hline Grecja & 0,7 & 0,8 & 0,7 & 0,9 & 0,9 & 0,9 & 0,9 & 1,0 & 1,0 & 0,9 \\
\hline $\begin{array}{l}\text { Hiszpania } \\
\text { (local government) }\end{array}$ & 2,7 & 2,7 & 2,8 & 3,2 & 3,3 & 3,4 & 4,2 & 4,1 & 3,7 & 3,3 \\
\hline state government & 5,9 & 5,7 & 6,6 & 8,6 & 11,4 & 13,6 & 18,1 & 20,5 & 22,9 & 24,4 \\
\hline Francja & $:$ & $:$ & : & : & $:$ & $:$ & 8,5 & 8,7 & 8,9 & 9,0 \\
\hline Chrowacja & $:$ & $:$ & $:$ & $:$ & 1,3 & 1,3 & 1,3 & 1,6 & 1,7 & 1,6 \\
\hline Włochy & 7,8 & 7,7 & 7,9 & 8,4 & 8,2 & 8,1 & 8,1 & 8,5 & 8,7 & 8,3 \\
\hline Cypr & : & $:$ & : & $:$ & : & $:$ & 1,6 & 1,6 & 1,6 & 1,5 \\
\hline Łotwa & $:$ & $:$ & $:$ & $:$ & $:$ & $:$ & 5,8 & 6,0 & 6,0 & 6,0 \\
\hline Litwa & 0,9 & 1,0 & 1,2 & 1,6 & 1,6 & 1,8 & 1,9 & 2,0 & 2,1 & 1,9 \\
\hline Luxemburg & 2,5 & 2,3 & 2,3 & 2,4 & 2,4 & 2,3 & 2,3 & 2,1 & 2,1 & 2,1 \\
\hline
\end{tabular}


Tabela $7 \mathrm{~cd}$.

\begin{tabular}{|l|r|r|r|r|r|r|r|r|r|r|}
\hline & $\mathbf{2 0 0 6}$ & $\mathbf{2 0 0 7}$ & $\mathbf{2 0 0 8}$ & $\mathbf{2 0 0 9}$ & $\mathbf{2 0 1 0}$ & $\mathbf{2 0 1 1}$ & $\mathbf{2 0 1 2}$ & $\mathbf{2 0 1 3}$ & $\mathbf{2 0 1 4}$ & $\mathbf{2 0 1 5}$ \\
\hline Węgry & 2,3 & 3,1 & 3,8 & 4,1 & 4,6 & 4,3 & 3,7 & 1,5 & 0,1 & 0,2 \\
\hline Malta & $:$ & $:$ & $:$ & $:$ & $:$ & $:$ & 0,1 & 0,1 & 0,1 & 0,0 \\
\hline Holandia & 7,6 & 7,1 & 7,3 & 7,9 & 8,3 & 8,6 & 8,8 & 8,8 & 8,5 & 8,3 \\
\hline Austria (local government) & $:$ & $:$ & $:$ & $:$ & $:$ & $:$ & 3,8 & 3,9 & 3,9 & 4,0 \\
\hline state government & $:$ & $:$ & $:$ & $:$ & $:$ & $:$ & 6,7 & 6,3 & 6,2 & 6,1 \\
\hline Polska & $\mathbf{2 , 4}$ & $\mathbf{2 , 2}$ & $\mathbf{2 , 3}$ & $\mathbf{3 , 0}$ & $\mathbf{3 , 8}$ & $\mathbf{4 , 2}$ & $\mathbf{4 , 2}$ & $\mathbf{4 , 3}$ & $\mathbf{4 , 3}$ & $\mathbf{4 , 2}$ \\
\hline Portugalia & 4,2 & 4,4 & 4,7 & 5,4 & 5,9 & 6,2 & 6,2 & 6,3 & 6,4 & 6,1 \\
\hline Rumunia & 1,2 & 1,7 & 1,8 & 2,3 & 2,4 & 2,5 & 2,6 & 2,5 & 2,5 & 2,5 \\
\hline Słowenia & 0,7 & 0,7 & 0,9 & 1,4 & 1,7 & 1,9 & 2,0 & 2,0 & 2,1 & 2,0 \\
\hline Słowacja & $:$ & $:$ & $:$ & $:$ & $:$ & $:$ & 2,3 & 2,2 & 2,2 & 2,3 \\
\hline Finlandia & $:$ & $:$ & $:$ & $:$ & $:$ & $:$ & 7,2 & 8,0 & 8,6 & 8,9 \\
\hline Szwecja & $:$ & $:$ & $:$ & $:$ & $:$ & $:$ & 8,1 & 8,7 & 9,4 & 10,1 \\
\hline Wielka Brytania & 4,2 & 4,2 & 4,4 & 4,4 & 4,5 & 4,5 & 5,0 & 4,9 & 4,8 & 4,8 \\
\hline
\end{tabular}

Gdzie: : - brak danych

Źródło: opracowanie własne na podstawie Statistics Database, Eurostat, protokół dostępu: http://ec.europa.eu/eurostat/data/database (17.02.2017).

na przeliczanie wartości deficytu zgodnie z nową, obowiązującą metodologią ESA 2010.

Zadłużenie podsektora local government dla 28 państw członkowskich Unii Europejskiej w 2015 r. wyniosło 5,9\% PKB. Największy poziom zadłużenia w 2015 r. (biorąc pod uwagę tylko podsektor local government) występował w Szwecji $(10,1 \%)$ Francji (9\%), Finlandii $(8,9 \%)$, Holandii $(8,3 \%)$, we Włoszech $(8,3 \%)$, Danii $(7,4 \%)$, natomiast najniższy, nieprzekraczający $1 \%$ PKB, dotyczy Malty, Węgrzech i Grecji. Polska, ze wskaźnikiem 4,2\% PKB, zaliczana jest do państw o niskim udziale długu podsektora samorządowego $\mathrm{w}$ relacji do PKB. Od 2011 r. poziom charakteryzował się względną stałością (niewielki wzrost do 4,3\% PKB nastapił w roku 2013 i 2014).

Interesujące są zbiorcze wyniki budżetowe podsektora samorzadowego w Polsce na tle innych państw członkowskich Unii Europejskiej (tabela 8).

$\mathrm{Z}$ danych zaprezentowanych w tabeli 8 wynika, że najgorszy wynik podsektora samorządowego we wszystkich krajach członkowskich został odnotowany w latach 2009 i 2010. W kolejnych latach sytuacja stopniowo zaczęła ulegać poprawie. Rekordowy zakres nierównowagi fiskalnej został odnotowany w Polsce w 2010 r., kiedy nasz kraj osiągnął najwyższy wskaźnik w porównaniu $\mathrm{z}$ innymi państwami UE. Wynosił on $1,2 \% \mathrm{PKB}$, czyli trzykrotnie więcej niż średnia UE-28. Począwszy od roku 2011 wskaźnik ten dla Polski zaczął ulegać zdecydowanej poprawie.

Szczegółowe informacje na temat wielkości zadłużenia podsektora samorządowego w Polsce zawarte sa w tabeli 9.

$\mathrm{Z}$ danych zawartych w tabeli 9 wynika, że obserwowany jest stały wzrost zadłużenia podsektora samorządowego w Polsce, które w 2015 r. stanowiło ponad 8\% zadłużenia sektora finansów publicznych. Zadłużenie podsektoroa samorządowego w Polsce ma zatem niewielki wpływ na zadłużenie sektora finansów publicznych (zdecydowanie największy wpływ na ujemny wynik sektora finansów publicznych ma podsektor rządowy). Najwiekszy wzrost zadłużenia podsektora samorządowego nastąpił w 2010 r. (w porównaniu $\mathrm{z}$ rokiem 2009 zadłużenie podsektora samorządowego wzrosło o $36 \%$ ). Największy udział w zadłużeniu podsektora samorządowego przypada na 
Tabela 8. Wynik podsektora local government w Polsce na tle pozostałych państw członkowskich UE-28 w latach 2006-2015 (jako \% PKB)

\begin{tabular}{|c|c|c|c|c|c|c|c|c|c|c|}
\hline & 2006 & 2007 & 2008 & 2009 & 2010 & 2011 & 2012 & 2013 & 2014 & 2015 \\
\hline UE-28 & $-0,2$ & $-0,1$ & $-0,2$ & $-0,4$ & $-0,4$ & $-0,2$ & $-0,1$ & $-0,1$ & 0,0 & 0,1 \\
\hline Belgia & $-0,1$ & 0,1 & 0,2 & 0,0 & $-0,1$ & $-0,2$ & $-0,5$ & $-0,2$ & $-0,2$ & 0,1 \\
\hline Bułgaria & 0,2 & $-0,1$ & $-0,4$ & $-0,8$ & 0,0 & 0,0 & 0,2 & 0,4 & 0,0 & $-0,9$ \\
\hline Czechy & $-0,3$ & 0,3 & $-0,1$ & $-0,6$ & $-0,4$ & $-0,3$ & $-0,1$ & 0,3 & 0,2 & 0,6 \\
\hline Dania & $-0,4$ & 0,0 & $-0,2$ & $-0,5$ & $-0,1$ & 0,1 & 0,0 & 0,2 & 0,2 & 0,2 \\
\hline Niemcy & 0,0 & 0,3 & 0,3 & $-0,2$ & $-0,3$ & 0,0 & 0,1 & 0,0 & $-0,1$ & 0,1 \\
\hline Estonia & $-0,2$ & $-0,4$ & $-0,6$ & $-0,5$ & 0,2 & 0,1 & $-0,2$ & $-0,5$ & 0,0 & 0,3 \\
\hline Irlandia & 0,2 & $-0,2$ & $-0,4$ & $-0,1$ & 0,0 & $-0,1$ & 0,0 & 0,0 & 0,0 & 0,3 \\
\hline Grecja & 0,0 & 0,0 & 0,0 & 0,0 & $-0,3$ & 0,2 & 0,3 & 0,4 & 0,3 & 0,3 \\
\hline Hiszpania & 0,1 & $-0,3$ & $-0,5$ & $-0,5$ & $-0,7$ & $-0,8$ & 0,3 & 0,6 & 0,5 & 0,5 \\
\hline Francja & $-0,2$ & $-0,4$ & $-0,5$ & $-0,3$ & $-0,1$ & 0,0 & $-0,2$ & $-0,4$ & $-0,2$ & 0,0 \\
\hline Chorwacja & $-0,1$ & 0,0 & $-0,1$ & $-0,7$ & 0,1 & $-0,1$ & 0,1 & 0,0 & $-0,1$ & 0,1 \\
\hline Włochy & $-1,0$ & $-0,1$ & $-0,2$ & $-0,4$ & $-0,4$ & $-0,2$ & 0,2 & 0,0 & 0,1 & 0,3 \\
\hline Cypr & $-0,1$ & $-0,1$ & 0,0 & $-0,1$ & 0,0 & $-0,1$ & 0,0 & 0,1 & 0,0 & 0,0 \\
\hline Łotwa & $-0,4$ & $-0,6$ & $-1,2$ & $-1,7$ & $-0,3$ & $-0,5$ & $-0,2$ & $-0,4$ & $-0,2$ & 0,3 \\
\hline Litwa & $-0,3$ & $-0,3$ & $-0,2$ & $-0,4$ & 0,1 & $-0,4$ & $-0,2$ & $-0,3$ & 0,1 & 0,3 \\
\hline Luxemburg & 0,2 & 0,4 & 0,5 & $-0,1$ & 0,2 & 0,3 & 0,5 & 0,4 & 0,3 & 0,4 \\
\hline Węgry & $-0,8$ & $-0,1$ & 0,1 & $-0,4$ & $-0,9$ & 0,6 & 0,5 & 2,5 & 1,4 & 0,2 \\
\hline Malta & 0,0 & 0,0 & 0,0 & 0,0 & 0,1 & 0,0 & 0,0 & 0,0 & 0,0 & 0,1 \\
\hline Holandia & $-0,3$ & $-0,4$ & $-0,7$ & $-0,8$ & $-1,1$ & $-0,7$ & $-0,4$ & $-0,4$ & $-0,2$ & $-0,3$ \\
\hline Austria & 0,0 & 0,0 & $-0,1$ & $-0,4$ & $-0,5$ & $-0,1$ & $-0,1$ & $-0,1$ & 0,0 & 0,0 \\
\hline Polska & $-0,3$ & 0,0 & $-0,2$ & $-1,1$ & $-1,2$ & $-0,7$ & $-0,3$ & $-0,2$ & $-0,2$ & 0,0 \\
\hline Portugalia & $-0,1$ & $-0,3$ & $-0,6$ & $-0,8$ & $-0,9$ & $-0,1$ & 0,5 & 0,2 & 0,4 & 0,5 \\
\hline Rumunia & 0,0 & $-0,2$ & $-1,0$ & $-0,7$ & $-0,1$ & $-0,6$ & $-0,5$ & 0,1 & 0,5 & 0,7 \\
\hline Słowenia & $-0,1$ & $-0,1$ & $-0,7$ & $-0,5$ & $-0,3$ & 0,1 & 0,1 & $-0,1$ & $-0,1$ & 0,3 \\
\hline Słowacja & $-0,2$ & $-0,1$ & $-0,1$ & $-0,7$ & $-0,9$ & $-0,1$ & 0,1 & 0,2 & $-0,1$ & 0,2 \\
\hline Finlandia & $-0,3$ & $-0,2$ & $-0,4$ & $-0,6$ & $-0,2$ & $-0,5$ & $-1,1$ & $-0,7$ & $-0,8$ & $-0,6$ \\
\hline Szwecja & 0,1 & 0,1 & $-0,1$ & $-0,2$ & 0,2 & $-0,3$ & $-0,2$ & $-0,1$ & $-0,4$ & $-0,2$ \\
\hline Wielka Brytania & $-0,2$ & $-0,2$ & $-0,4$ & $-0,5$ & $-0,2$ & $-0,3$ & $-0,5$ & $-0,3$ & 0,0 & $-0,2$ \\
\hline
\end{tabular}

Źródło: opracowanie własne na podstawie Statistics Database, Eurostat, protokół dostępu: http://ec.europa.eu/eurostat/data/database (21.02.2017). 
Tabela 9. Zadłużenie sektora finansów publicznych w Polsce po konsolidacji (wg nominału, w mln zł)

\begin{tabular}{|l|r|r|r|r|r|r|r|}
\hline & XII 2009 & XII 2010 & XII 2011 & XII 2012 & XII 2013 & XII 2014 & XII 2015 \\
\hline $\begin{array}{l}\text { Zadłużenie } \\
\text { sektora finansów } \\
\text { publicznych }\end{array}$ & 669876,40 & 747898,80 & 815342,60 & 840476,80 & 882293,00 & 826772,20 & 877 282,40 \\
\hline $\begin{array}{l}\text { Zadłużenie } \\
\text { podsektora } \\
\text { samorządowego, } \\
\text { w tym: }\end{array}$ & 39324,70 & 53519,00 & 64257,70 & 67398,30 & 68397,60 & 71660,60 & 72072,90 \\
\hline $\begin{array}{l}\text { 1. Jednostki } \\
\text { samorządu } \\
\text { terytorialnego } \\
\text { i ich związi }\end{array}$ & 36371,30 & 50568,40 & 61186,60 & 64020,20 & 65210,10 & 68264,50 & 68351,7 \\
\hline $\begin{array}{l}\text { 2. Samodzielne } \\
\text { publiczne } \\
\text { zakłady opieki } \\
\text { zdrowotnej }\end{array}$ & 2916,50 & 2869,50 & 2999,80 & 3314,10 & 3129,10 & 3331,00 & 3625,50 \\
\hline $\begin{array}{l}\text { 3. Samorządowe } \\
\text { instytucje } \\
\text { kultury }\end{array}$ & 27,1 & 61,6 & 63,2 & 58,1 & 54,5 & 61,7 & 63,1 \\
\hline $\begin{array}{l}\text { 4. Pozostałe } \\
\text { samorządowe } \\
\text { osoby prawne }\end{array}$ & 9,7 & 19,5 & 8,2 & 5,9 & 3,8 & 3,4 & 32,6 \\
\hline
\end{tabular}

Źródło: opracowanie własne na podstawie danych Ministerstwa Finansów za poszczególne lata, protokół dostępu: http://www.finanse.mf.gov.pl/zadluzenie-sektora-finansow-publicznych (21.02.2017).

jednostki samorządu terytorialnego (JST) i ich związki, a także na samodzielne publiczne zakłady opieki zdrowotnej.

W kontekście niniejszego opracowania interesujace sa przede wszystkim rozmiary i dynamika zadłużenia jednostek samorządu terytorialnego, wyniki budżetów oraz wyniki operacyjne (tabela 10). Wynik budżetu operacyjnego JST (nadwyżka operacyjna, deficyt operacyjny) ma bardzo istotne znaczenie poznawcze. Stanowi jeden z najistotniejszych wskaźników sytuacji finansowej JST, ilustrujac, czy jednostka samorzadu terytorialnego jest $\mathrm{w}$ stanie pokryć wydatki bieżace dochodami bieżacymi. Jeśli wydatki bieżące są wyższe od dochodów bieżących (deficyt operacyjny), oznacza to, że wydatk te realizowane są na poziomie przekraczającym możliwości finansowe JST.

Analiza danych zawartych w tabeli 10 pozwala na sformułowanie wniosków dotyczących określonych trendów związanych z zadłużaniem się samorządów. W przedstawionym okresie wystąpiło duże zróżnicowanie w wielkościach dochodów i wydatków JST ogółem. W latach 2006-2010 wystąpił proces narastania się deficytów budżetowych (w 2009 roku deficyt budżetów JST był prawie 5-krotnie wyższy niż w roku 2008). Największy poziom deficytu budżetów JST został odnotowany w 2010 roku. Następnie wskaźnik ten obrał tendencję malejącą, by w 2015 r. wynik budżetów JST był wartością dodatnią (nadwyżka). Istotne zmiany zaobserwowano także w zakresie kształtowania się średniej relacji wielkości zadłużenia JST do dochodów. Najwyższy wzrost tego wskaźnika odnotowano w roku 2010 (wzrost o 7,8\%, tj. z poziomu $26 \%$ w 2009 r. do poziomu 33,8\% w 2010). Zadłużenie JST w relacji do zrealizowanych dochodów osiągnęło najwyższą wartość w 2011 roku.

W odniesieniu do wyników operacyjnych sytuacja polskich JST była zdecydowanie lepsza. We wszystkich latach analizowanego okresu występowała nadwyżka operacyjna pomimo deficytowego wyniku budżetowego JST. Jedynie w roku 2015 można zaobserwować zarówno nadwyżkę operacyjną, jak i dodatni wynik budżetów JST. Nadwyżka operacyjna informuje, jakimi środkami dysponuje jednostka po pokryciu najbardziej 
Tabela 10. Rozmiary zadłużenia JST w Polsce na tle wyników budżetowych i w relacji do zrealizowanych dochodów budżetowych

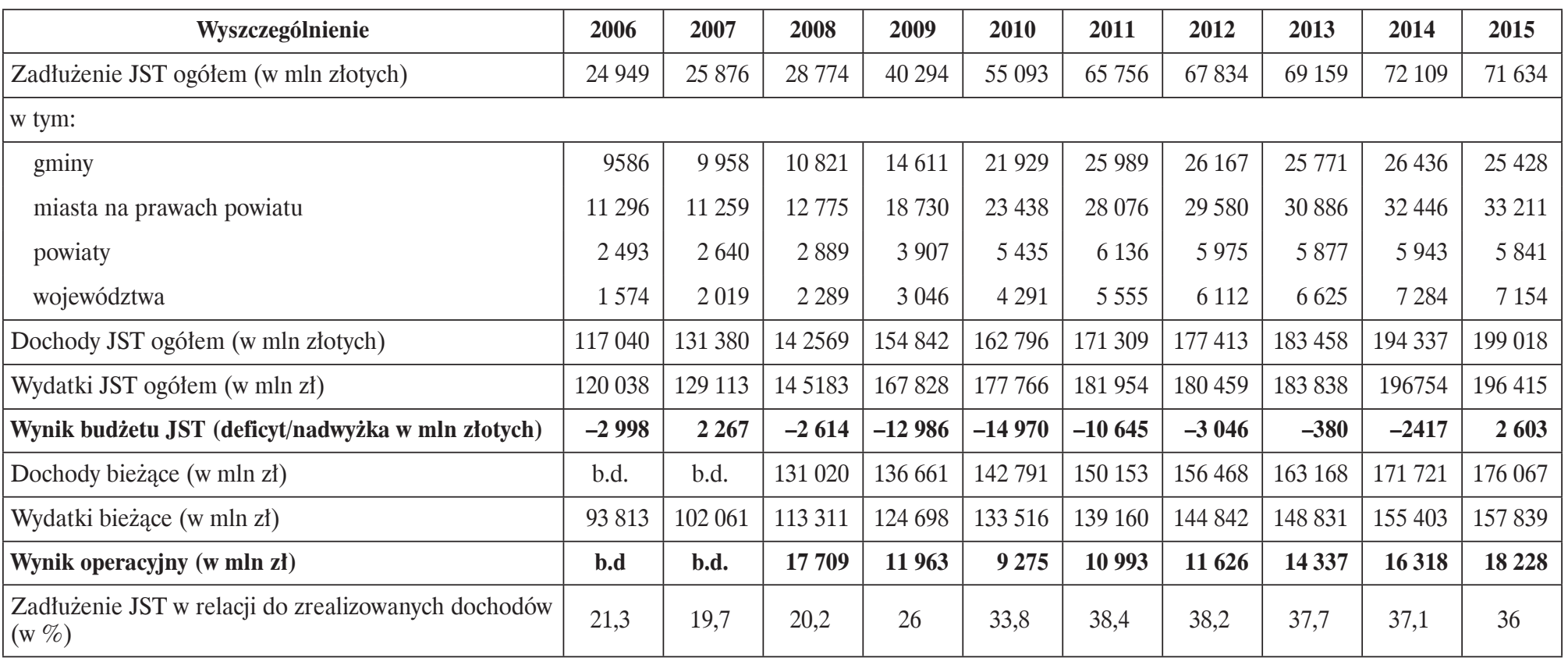

Gdzie: b.d. - brak danych

Źródło: opracowanie własne na podstawie sprawozdań z działalności regionalnych izb obrachunkowych i wykonania budżetu przez JST za poszczególne lata. 
podstawowych potrzeb bieżących, a którą jednostka może przeznaczyć na przykład na inwestycje bądź spłatę zadłużenia. Najwyższy wzrost nadwyżki operacyjnej wystąpił w roku 2013 (w porównaniu z rokiem 2012 wynik operacyjny zwiększył się o 23\%). Analizowany okres charakteryzował się dużą rozbieżnością poziomu wyniku operacyjnego. Najmniejszy poziom wystapił w roku 2010 (9 275 mln zł), podczas gdy w roku 2015 wynik operacyjny $\mathrm{w}$ porównaniu $\mathrm{z}$ rokiem 2010 był dwukrotnie wyższy. Występowanie takiej nadwyżki operacyjnej jest niewątpliwie zjawiskiem pozytywnym, jednak nie przesądza to o dobrej kondycji finansowej danej JST.

\section{Zakończenie}

$\mathrm{W}$ porównaniu $\mathrm{z}$ innymi państwami członkowskimi Unii Europejskiej podsektor samorządowy w Polsce odznacza się dobrą sytuacją finansową. Polska zaliczana jest do państw o niskim udziale długu podsektora samorządowego w relacji do PKB, a także o jednym $\mathrm{z}$ najwyższych udziałów procentowych dochodów i wydatków podsektora samorządowego w sektorze finansów publicznych. Pomimo tego rośnie też zadłużenie w tym podsektora. Spowodowane jest to kilkoma czynnikami. Zmiany w prawie poskutkowały obowiązkiem wykonywania przez JST nowych zadań, na finansowanie których JST nie miały wystarczających środków. Inna determinantą wzrostu zadłużenia podsektora samorządowego w Polsce były inwestycje współfinansowane ze środków pomocowych UE. Projekty takie opieraja sie na zasadzie wspólfinansowania, zgodnie z którą dofinansowanie UE ma uzupełniać fundusze własne beneficjenta (w tym przypadku JST). Wymagany jest określony wkład własny, a w kontekście ograniczonych dochodów własnych JST korzystają ze środków uzyskanych z instrumentów zwrotnych.

Znajomość wielkości zadłużenia JST jest istotna, szczególnie z punktu widzenia władz samorządowych. Należy jednak pamiętać, że jeżeli dług jest wykorzystywany w sposób właściwy, stanowi też wydajny instrument polityki fiskalnej.

\section{Bibliografia}

Alińska, A. i Woźniak, B. (2015). Wspótczesne finanse publiczne. Warszawa: Difin.

Bitner, M. (2016). Prawne instrumenty ograniczania deficytu budżetowego i dtugu publicznego jednostek samorzadu terytorialnego. Warszawa: Wolters Kluwer Polska.

Jastrzębska, M. (2012). Finanse jednostek samorzadu terytorialnego. Warszawa: Wolters Kluwer Polska.

Jóźwiak, M. (2014). Pojęcie długu. Statystyka długu publicznego. Metodologia ustalania zadłużenia. W: P. Walczak (red.), Zadtużenie jednostek samorzadu terytorialnego. Wyzwania $w$ obliczu nowej perspektywy finansowej UE. Warszawa: Wydawnictwo C.H. Beck.

Kopits, G. i Symanski, S. (1998). Fiscal policy rules. Washington: „IMF Occasional Paper”.

Lotko, E. i Zawadzka-Pąk, U.K. (2016). Problemy terminologiczne i definicyjne deficytu i długu w polskim i unijnym prawie finansów publicznych. Prawo Budżetowe Państwa i Samorząu, 2(4).

Marchewka-Bartkowiak, K. (2012). Reguły fiskalne w warunkach kryzysu finansów publicznych. Ekonomia i Prawo, 3.

Poniatowicz, M., Salachna, J.M. i Perło, D. (2010). Efektywne zarzadzanie dtugiem $w$ jednostce samorzadu terytorialnego. Warszawa: Wolters Kluwer Polska.

Poniatowicz, M. (2014). Wptyw kryzysu gospodarczego na systemy finansowe jednostek samorzadu terytorialnego. Na przyktadzie największych miast $w$ Polsce. Warszawa: Wydawnictwo CeDeWu.

Sprawozdania z wykonania budżetów jst w latach 2006-2015 - informacje Ministerstwa Finansów,http://www.mf.gov.pl/ministerstwo-finansow/dzialalnosc/finanse-publiczne/budzety-jednostek-samorzadu-terytorialnego/sprawozdania-budzetowe

Sprawozdania z działalności regionalnych izb obrachunkowych i wykonania budżetu przez jednostki samorządu terytorialnego w latach 2006-2015, http://www.rio.gov.pl/.

Spychała, J. (2015). Wydatkowe reguły fiskalne jako instrument dyscyplinujący finanse publiczne. Wspótczesne problemy ekonomiczne. Zeszyty Naukowe Uniwersytetu Szczecińskiego, 11.

Statistics Database, Eurostate, protokół dostępu: http://ec.europa.eu/eurostat/data/database

Ustawa z dn. 27 sierpnia 2009 r. o finansach publicznych, Dz.U. 2009 Nr 157 poz. 1240 z późn. zm. 